\section{THE WILLARD GIBBS PROFESSORSHIP OF RESEARCH IN PURE CHEMISTRY}

IN course of the academic year 1914-15, a now department was established on a permanent basis in the Mellon Institute of Industrial Research of the University of Pittsburgh, namely, a department of research in pure chemistry. The headship of this department is to be known as the Willard Gibbs Professorship of Research in Pure Chemistry, "to ever proclaim the ideal which the incumbents of the chair and the groups of research workers to be associated with them will be expected to follow." It constitutes a chair in the graduate school of the University of Pittsburgh as well as in the Mellon Institute.

Dr. Martin A. Rosanoff, who had built up and for years headed the graduate department of chemistry in Clark University, was formally inaugurated as the first permanent incumbent of this professorship, at exercises held in the Assembly Hall of the Mellon Institute on October 26. The exercises included addresses by Professors James McKeen Cattell and Marston Taylor Bogert, both of Columbia University, and by Dr. Rosanoff, followed by a reception and an inspection of the Mellon Institute.

Chancellor Samuel Black McCormick presided at the exercises. He explained the circumstances connected with the establishment of the chair and thanked the donors whose generosity had made possible the endowment, of which the income, amounting to $\$ 5,000$ per annum, is to constitute the salary of the incumbent of the chair. He then introduced Dr. Cattell.

Dr. Cattell spoke on "The Support of Scientific Research in a Democracy."

His argument was that science with its applications had given us democratic institutions by so greatly increasing the productivity of labor and the length of life, that it had become possible to provide for education and equality of opportunity. But scientific research, unlike most services, can not be sold to individuals; it is for the benefit of all and must be paid for by all. Hitherto aristocratic institutions have been more favorable to scientific research than ours, but we are now beginning to equal the leading European nations in our contributions to the advancement of science. We must do much more in the future. Coal is mined in Pennsylvania to the value of some three hundred million dollars a year. In so far as natural resources are consumed, ten per cent. of the proceeds-thirty million dollars a year-might very properly be devoted to discovering new ways to obtain energy. The manufactures of the city of Pittsburgh and of Allegheny County are worth more than three hundred million dollars a year. These, like the proceeds of the mines, have been made possible by the applications of science. Ten per cent. of their value-another thirty million dollars a year-might to advantage be spent in this city for the further advancement of science under the auspices of the University of Pittsburgh. By the Bessemer steel process the world saves, according to the estimates of the late Abram S. Hewitt, each year two billion dollars; by the electro-magnet discovered by Faraday in the only research laboratory then existing, the world earns each year perhaps twice as much. Why should not these six billion dollars a year be set aside as a memorial to the scientific men and workers in technology who have provided the world with its vast wealth, to be used for the further increase of this wealth and for the welfare of all? We could afford to devote one tenth of all labor, one fourth of all wealth, to scientific work, and we should become each year a richer and a greater nation. We need a Mellon Institute for each science and in every city.

Following Dr. Cattell, Dr. Bogert, who was introduced by Dr. Raymond F. Bacon, director of the Mellon Institute, spoke on "The Especial Value of Research in Pure Chemistry."

After rapidly reviewing some of the more striking contributions which chemistry has made to civilization, he pointed out that it was research in pure science which laid the deep and abiding foundations upon which applied science has erected all the wonderful structure of modern industrial processes. The nineteenth century has been called the Age of Physics and Engineering, but the twentieth will surely be the Age of Chemistry.

Dr. Bogert referred to the great service 
which the University of Pittsburgh and its Mellon Institute are now rendering the public, and congratulated them upon the establishing of the new chair of research in pure chemistry as one of the most effective ways of furthering research and a momentous step in the direction of building up a splendid new graduate school. He believed that a university's true greatness was not measured by the magnificence of its plant, the size or athletic prowess of its student body, but by excellence of its graduate school, and that the standard of the latter was determined by the amount and quality of its production of genuinely original work, and the character of its faculty. He said, further, that the extent of the assistance which a university secures from its surrounding community in the creation of such a fine graduate school as that of the University of Pittsburgh was often a good indication of the attitude of the university authorities themselves toward such work. In this respect he said that the University of Pittsburgh was, indeed, fortunate in having a chancellor and trustees who knew how to prize original scientific investigation at its real worth, and under whose fostering care and guidance it would have full opportunity to grow and flourish.

The designation of the new chair as the Willard Gibbs professorship of research in pure chemistry was peculiarly appropriate, and should prove a constant inspiration to all incumbents in their search for truth. Dr. Bogert also congratulated the chancellor and Director Bacon upon securing as the first occupant of the chair so distinguished a scientist as Dr. Rosanoff-chemist, physicist, mathematician and linguist-whose investigations, especially those on distillation and the catalysis of organic reactions, have already won for him an enviable international reputation. $\mathrm{He}$ then felicitated Dr. Rosanoff upon his appointment to a post of such conspicuous dignity and honor. In closing, the speaker called attention to the fact that it was the development of genius that was of greatest concern to the world, and that many of the investigations carried out by the Willard Gibbs professors would undoubtedly survive long after the beautiful buildings of the university had crumbled in decay.

The last of the addresses was a brief discourse on Willard Gibbs's life and work by Dr. Rosanoff. In the conclusion of his address, Dr. Rosanoff expressed the sentiment that a man whose intellectual achievement is as wonderful as that of Willard Gibbs need hardly be honored either by a monument in stone or bronze or even by so magnificent a memorial as a professorship of research endowed in perpetuity. The sense of attaching his illustrious name to the new chair is really the hitching of the wagon to a star. And Dr. Rosanoff solemnly pledged himself, ever guided by the light of that star, to humbly follow in the steps of the great American master of scientific research.

The Department of Research in Pure Chemistry of the Mellon Institute is to be conducted along the same lines as similar departments in the leading universities in this country and abroad. Graduates of colleges in good standing will be admitted to it as candidates for the master's and doctor's degrees, and it will be the principal duty of the head of the department to maintain in it the highest attainable academic standard. The industrial research fellows of the Mellon Institute and the members of the faculty of the school of chemistry of the University of Pittsburgh, as well as the members of the Federal Bureau of Mines and of Standards, are at liberty to attend all lectures, seminars, and other exercises conducted in the department. Further, the head of the new department promotes the industrial ends of the Mellon Institute by any scientific advice that he may be able to give in connection with the work of the industrial research fellows. ${ }^{1}$

The department of research in pure chemistry occupies a suite of rooms in the Mellon Institute building ${ }^{2}$ and its members are at liberty to draw on the material facilities of the institute on the same terms as the members of

1 On the object and work of the Mellon Institute, see J. Ind. Eng. Chem., 7 (1915), 343.

2 For a description of this building, see $J$. Ind. Eng. Chem., 7 (1915), 333. 
the industrial section. Those of the graduate students who are granted the title of fellow in pure chemistry are considered by the Mellon Institute as equal in rank and privileges with the industrial research fellows.

\section{W. A. HAMOR ${ }^{3}$}

\section{FREDERIC WARD PUTNAM}

THE following minute on the life and services of Professor Putnam was placed upon the records of the Faculty of Arts and Sciences of Harvard University at the meeting of October 26, 1915:

Frederic Ward Putnam, son of Ebenezer and Elizabeth Appleton Putnam, was born in Salem, Massachusetts, April 16, 1839. His ancestors on both sides were early immigrants from England, the first American ancestor being John Putnam, who settled in Salem in 1640. The father, grandfather and great-grandfather of Professor Putnam were all graduates of Harvard College, and the associations of his mother's family had been close with the institution from its beginning.

His early schooling was received in private schools and at home under his father's tuition. At an early age he showed great interest in natural history and had thoughts of devoting himself to scientific pursuits. Promised an appointment at West Point, however, he was preparing himself to adopt a military career, when Louis Agassiz met him at the Museum of the Essex Institute, and, recognizing in him a keen student, persuaded him to take up natural history as his life work. His preparation for the military profession was accordingly abandoned, and he devoted himself at once to the study of birds, being made curator of ornithology in the Essex Institute in 1856. In the following year he was made assistant to Professor Agassiz, and entering the Lawrence Scientific School received the degree of S.B. in 1862. For a number of years after this, he continued his work in the study of animal life, as curator of vertebrates at the Essex Institute, of Ichthyology at the Boston Society of Natural History, and as assistant in the museum of comparative zoology at Harvard University. During these years he had also some experience in museum administration, as he was entrusted with the charge of the Museum of the Essex Institute and of the Museum of the East Indian Marine Society in Salem, and later

3 Assistant to the director of the Mellon Institute of Industrial Research. was made director of the museum of the Peabody Academy of Science in the same eity. In 1873 he was chosen to fill the important position of permanent secretary of the American Association for the Advancement of Science, an office which he held for twenty-five years. Professor Putnam's connection with the association lasted through one of the most important periods in its life, and to his energy and administrative ability much of its success was due.

Although it was in the field of natural history that Professor Putnam for many years carried on most of his work, his interest in archeology was early aroused. While attending the meeting of the American Association at Montreal in 1857, he discovered on Mt. Royal a small kitchen-midden, and was thus among the very first in this country to recognize the presence of the remains of prehistoric man. In 1874 Dr. Jeffries Wyman, the first curator of the Peabody Museum of American Archeology and Ethnology, died and Professor Putnam was appointed to take the place. Thus began his connection with the institution of which he was the director for over forty years. In 1886 , he was made Peabody professor of American archeology and ethnology, and served as such until 1909, when he joined the group of the emeriti. During the nearly half-century of his connection with the museum, he labored unceasingly to build up its collections, both by purchase and by explorations in the field. He was one of the earliest to realize the need of archeological and anthropological exploration, and to insist that careful fieldnotes and data are equally important with the specimens themselves. The great collections which he gathered and which place the museum in the forefront of the museums of this country, are a witness of his success.

With the appointment to the Peabody professorship, Harvard University became one of the first institutions in the country to offer instruction in the field of anthropology and American archeology. Although always more active in museum and field-work than in teaching, Professor Putnam strove constantly to develop the instruction in his chosen science, from the time when, before any courses were offered, he had several voluntary students working under his direction, to the very last days of his life, when nearly a score of specialized courses were offered by the division of which ne had for so long been the head.

Striking as were the results of his work here at Harvard, his influence was literally nation wide, and he may justly be called one of the fathers of 